University of Wollongong

Research Online

Faculty of Business - Papers (Archive)

Faculty of Business and Law

$1-1-2011$

Product deletion: a critical overview and empirical insight into this process

Jonathan Muir

Bradford University

Nina Reynolds

University of Wollongong, ninar@uow.edu.au

Follow this and additional works at: https://ro.uow.edu.au/buspapers

Part of the Business Commons

Research Online is the open access institutional repository for the University of Wollongong. For further information contact the UOW Library: research-pubs@uow.edu.au 


\title{
Product deletion: a critical overview and empirical insight into this process
}

\author{
Abstract \\ With organisations as diverse as Heinz, Kraft, Polygram and Sony reducing the scope of their product \\ portfolios, it appears that the issue of product deletion is currently exercising managerial minds. Those \\ keen to pursue their interest in this area will find a concise body of work spanning nearly six decades. \\ However, missing from this work is an understanding of the recurring tactical, strategic and cultural \\ variables involved in deletion decision-making. This research sought to alleviate this shortcoming through \\ conducting an in-depth literature review and considering the deletion experiences of three world- \\ renowned organisations. The results of this exploratory study provide an initial insight into the core \\ product deletion variables, providing managers and academics with valuable up-to-date information on \\ this contemporary subject matter.

\section{Keywords} \\ deletion, into, process, overview, this, empirical, critical, insight, product \\ Disciplines \\ Business

\section{Publication Details} \\ Muir, J. \& Reynolds, N. (2011). Product deletion: a critical overview and empirical insight into this process. \\ Journal of General Management, 37 (1), 5-30.
}




\title{
Product deletion: a critical overview and empirical insight into this process
}

\author{
Jonathan Muir \\ Bradford University School of Management \\ Nina Reynolds \\ Southampton University Management School
}

\begin{abstract}
With organisations as diverse as Heinz, Kraft, Polygram and Sony reducing the scope of their product portfolios, it appears that the issue of product deletion is currently exercising managerial minds. Those keen to pursue their interest in this area will find a concise body of work spanning nearly six decades. However, missing from this work is an understanding of the recurring tactical, strategic and cultural variables involved in deletion decision-making. This research sought to alleviate this shortcoming through conducting an in-depth literature review and considering the deletion experiences of three world-renowned organisations. The results of this exploratory study provide an initial insight into the core product deletion variables, providing managers and academics with valuable up-to-date information on this contemporary subject matter.
\end{abstract}

\section{Introduction}

Over five decades ago Marvin (1959, p. 107) indicated that for organisations 'prosperity and growth are results of soundly planning product "portfolios"'. Day (1977), Goldgehn and Lagrace (1983) and Procter and Hassard (1990) called for senior managers to become more actively involved in product portfolio management. Similarly, Wind and Mahajan (1981), Snelson and Hart (1991) and Cooper, Edgett and Kleinschmidt (1999) outlined the need for managers to monitor and where need be, adapt their product portfolio(s) either through the introduction of new products and/or the deletion of existing products. New product development has received considerable academic and managerial attention, aided no doubt, by the potential rewards, risks and the glamour associated with the area (Alexander, 1964). Interest in product deletion, an activity involving the decision to 'discontinue the production and marketing of a product' (Avlonitis, 1986a; p. 1) either through replacing a product with an alternative offering or eradicating a product altogether, has been more sporadic. However, after two decades characterised by product proliferation (Petromilli, Morrison and Million, 2002; Frost, 2004) it appears that the situation is changing. For example, Unilever introduced the 'Path to 
Growth' strategy aiming to reduce the organisation's brand portfolio by $75 \%$ (Marsh, 2001). Procter and Gamble embarked on a similar 'Organisation 2005' initiative (Michaels, 2000). Sony, Heinz and Japanese cosmetics giant, Shiseido have sought to rationalise their product portfolios (Sanchanta, 2007; Frost, 2004; Grant, 2005). Even products with the royal seal of approval are not immune from such activities. Duchy Originals, the company established by Prince Charles, heir to the British throne, recently halved its product range (Wood, 2009). With rapid technological change, competitive pressure and poor economic conditions increasing the importance attributed to product deletion (Worthing, 1975; Avlonitis, 1986a) the current economic malaise is likely to increase the pressure on organisations to delete peripheral products which inhibit an organisation's profitability. ${ }^{1}$ In this situation, managers and academics may look to the existing product deletion literature for guidance: in doing so they will find a concise, apposite body of literature. However, missing from this literature is a contemporary overview adopting Webster's (1992, 2005) 'expanded view' of marketing outlining the fundamental tactical (e.g. the four Ps), strategic (e.g. the markets served, targeting, positioning, in essence how the organisation competes in its designated sector) and cultural (e.g. organisational cognition, norms of behaviour) variables associated with product deletion decision-making. The following paper seeks to address this shortcoming, by drawing on the literature to identify:

- Key tactical and strategic variables associated with each stage of the conventional product deletion process.

- The recurring cultural issues influencing product deletion decision-making and their saliency in a modern day context as well as using primary and secondary data analysis to provide a practical guide to deletion decisionmaking.

The research is exploratory in nature, case study driven (Yin, 2008) and aimed at illustrating topical issues and the state of current knowledge on product deletion. The intention is to highlight themes and issues to frame and shape further theory development and empirical testing.

\section{Product deletion: literature overview}

A significant proportion of the conceptual writings penned during what Argouslidis and McLean (2003) termed the 'non-empirical phase' (1952 to 1978) suggest product deletion decision-making is a sequential process with deletion candidates tending to be weak products that have fallen short of their sales, profits and/or market share expectations (Vyas, 1993). While a series of conceptual frameworks were introduced during this period their applicability has since been queried. Avlonitis (1986a, p. 62) believed these frameworks to be 'distilled from somewhat limited experience, common sense, and logic' with 'distinct overtones of evangelical fervour'. Kotler (1965) and Alexander (1964, p. 62), two of the original protagonists, cast further doubts on these frameworks the latter stating: 'Exactly what these [elimination] policies

${ }^{1}$ See Bereson (1963), Kotler (1965) and Evans (1977) for further details. 
should be, what form these procedures should take and to whom the job should be assigned, are matters that must vary with the structure and operating methods of the firm'. Alongside the tactical and strategic variables, a number of cultural issues were also addressed during the non-empirical phase. For example, Kotler (1965) discussed employees' aversion to product deletion and the subsequent use of organisational politics.

The initial conceptualisations of the product deletion process were quickly superseded during the early empirical phase (1970-1979) (Argouslidis and McLean, 2003). Researchers examined the deletion practices of a variety of organisations operating in the industrial and consumer goods sectors (Rothe, 1970; Eckles, 1971; Pletcher, 1973; Banville and Pletcher, 1974; Hise and McGinnis, 1975). This work, while useful, suffered from a lack of cohesion and the use, at times, of small, non-representative samples, as well as the dominance of US-based organisations (Avlonitis, 1986a). Limited regard was also given to additional situational, organisational or environmental factors which could influence organisations' deletion decision-making.

More recently, understanding of the product deletion process has progressed with a number of authors making extensive contributions to the area (e.g. Avlonitis and James, 1982; Avlonitis, 1983, 1984, 1985, 1986, 1987, 1989, 1993; Hart, 1988, 1989, 1990; Avlonitis, Hart and Tzokas, 2000). These authors considered the product deletion process used by UK industrial and consumer goods organisations and how these processes can be affected by various contextual elements. Hart (1990) and Avlonitis (1983, 1985, 1986a) also commented on a number of cultural issues including employee involvement in deletion decision-making, the frequency with which organisations address deletion issues, and the level of formality to adopt. This work culminated in the production of a product deletion typology, something that could 'contribute to a more effective and streamlined approach to decision making in this area' (Avlonitis, Hart and Tzokas, 2000, p. 42). The typology provides a useful 'short hand device' facilitating comparisons (Hambrick, 1983). However, it uses data collected nearly three decades ago. As such, the age of the information used to construct the typology is of concern as the intervening period has been characterised by considerable change with increased merger and acquisition activities, heightened competition and more generic product offerings (Dimitratos, McDonald and Tüselmann, 2003; Betts, 2006). The retail climate has also changed with the emergence of an oligopolistic market (Bell, Davies and Howard, 1997). Given the dramatically different contemporary environment there is a need to question whether Avlonitis, Hart and Tzokas's (2000) deletion typology is still applicable. While the deletion frameworks introduced over the last fifty years may aid product deletion decision-making, they tend to be conceptual in nature and reliant on old and/or sector specific data. A number of cultural issues are discussed. However, no attempt has been made to ascertain the central, recurring cultural issues associated with product deletion nor how organisations today actually deal with these issues. Thus, while the previous writings are informative, they fail to provide an overview of the central tactical, strategic and cultural variables involved in the deletion decision-making process. As such, the aims of the paper are valuable and timely. 


\section{Method}

An exhaustive electronic (and where needed, manual) search for relevant journal articles using a variety of academic and practitioner databases and information sources (e.g. Emerald, JSTOR, EBSCO, Caravan) was conducted to locate the available product deletion literature. Keywords such as - 'product' 'deletion' 'elimination' 'abandonment' 'exit' 'phase out' 'elimination' 'portfolio management', 'mix management' were used. The resulting information was systematically analysed to identify the recurring tactical, strategic and cultural elements associated with product deletion. In order to gain a contemporary insight into the cultural elements the findings from the literature were considered alongside the experiences of three large fast-moving consumer goods (FMCG) organisations: a world renowned household care and healthcare organisation based in the USA (Mop), a UK-based hot drinks/ foodstuffs provider (Cake) and a personal healthcare organisation (Tablet) with its headquarters in the UK. The names have been disguised at the request of the companies concerned. A case study approach was adopted as it was deemed appropriate for investigating how decisions are made in practice and the implicit/underlying reasons and opinions associated with the decisionmaking process (Schramm, 1971; Carroll and Johnson, 1990). Yin (2008) clarifies the roles of even a limited number of case studies in identifying and illustrating interesting situations and helping build theoretical knowledge. A convenience sample of three large FMCG organisations was chosen here for a number of reasons. Firstly, such organisations face intense competition, a situation that is likely to prompt the consideration of cost saving measures such as product deletion (Avlonitis, 1986a). Secondly, with a shift in power from manufacturing to retail organisations (Kotzab and Teller, 2003; Dawson and Shaw, 1990; Olver and Farris, 1989) the emergence of an oligopolistic European grocery retail sector (Quelch and Harding, 1996; Bell, Davies and Howard, 1997; Tomkins, 2000) and increasing consumer confusion caused by burgeoning product lines (Avlonitis, Hart and Tzokas, 2000; Buckley, 2002 and Seth, 2004) product deletion activities are a key concern for organisations heavily reliant on the retail sector (e.g. organisations providing consumer goods/FMCG products). Finally, the deletion experiences of large organisations vary more from one organisation to the next when compared to smaller organisations (Avlonitis 1987, 1993). So through focusing on large organisations a broad range of information/insights can be obtained. Mop, Tablet and Cake were singled out as they each met the required criteria and further to this the three organisations represented a range of large FMCG organisations. Mop is a truly omnipresent organisation operating in numerous sectors and with its brands available in over 180 countries. Tablet operates in numerous countries but focuses on a select number of product categories. Cake is an international company yet it focuses predominantly on the UK market. The data was collected over a three-year period from 2003 to 2006.

Data was collected from all three organisations via: (a) a total of 25 in-depth interviews/informal discussions, each lasting between 45 minutes and 3.5 hours (b) seven brief follow up questionnaires clarifying points raised in the discussions and (c) direct involvement with a four month, in-house, project 
investigating the relevance of the personal healthcare organisation's product portfolio within selected markets. In order to investigate the complex and interrelated nature of deletion decision-making, the emphasis was placed on the organisation's general approach to the issue rather any individual deletion decisions encountered. With Avlonitis, Hart and Tzokas (2000, p. 44) indicating that personnel from the sales and marketing departments tend to have 'the most complete knowledge of the product deletion decisions in their firms' and Vyas (1993) championing the marketers 'watchdog' position on product deletion, the research sought out the opinions of such informants. However, to gain a comprehensive view, managers working in a variety of departments (e.g. manufacturing, logistics, finance, account management) were also interviewed. The number of interviews conducted varied from one organisation to the next. This is attributed to the varying degrees of access and the number of suitable interviewees available. The number of interviews does not detract from the quality of the information collected and the insights provided. For example, in the case of Cake, while only three interviews were conducted two of the interviews lasted over three hours and involved two of the organisation's six board members. The positions of the informants within each organisation are detailed in Table 1.

The data analysis used Miles and Huberman's 'rigorous' six stage approach (Easterby-Smith, Thorpe and Lowe, 1997). A colour-coding scheme was adopted with various colours allotted to the different stages of the product deletion process and the differing product deletion issues addressed. With the literature review and primary data analysis complete the colour-coded data was brought together. This process enabled the systematic dissection of the literature and empirical data helping to reveal the relevant themes.

\section{Results}

The results have been broken down into two sections. The first section summarises the literature highlighting the tactical and strategic variables associated with each stage of the product deletion process. The second section offers a discussion on the recurring cultural factors that impact on product deletion decision-making and considers the applicability of these cultural factors within the three case study organisations.

\section{Strategic and tactical considerations}

The literature reveals that the strategic and tactical factors associated with deletion decision-making vary in accordance with organisational idiosyncrasies. Nevertheless, there are a number of recurring variables corresponding to each stage of the product deletion process. Figure 1 presents these variables indicating whether they are discussed as strategic $(S)$ and/or tactical $(T)$ factors. Some variables are clearly one or the other. However, a few can be strategic to the organisation as a whole, but in terms of product deletion decision-making they are more tactical in nature. Financial recognition and evaluation variables, for instance, are clearly of strategic concern at an organisational level (e.g. the attainment of certain profit levels). Yet within the deletion context they act as triggers to, or measures of, the viability of 
Table 1: Primary research information sources

\begin{tabular}{|c|c|c|}
\hline Organisation & Information source & Occupation \\
\hline \multirow{15}{*}{$\begin{array}{l}\text { TABLET } \\
\text { Personal healthcare } \\
\text { organisation }\end{array}$} & Informant 1 & Sales Representative \\
\hline & Informant 2 & Marketing Consultant \\
\hline & Informant 3 & Senior Account Manager \\
\hline & Informant 4 & Marketing Director \\
\hline & Informant 5 & Demand Planning Director \\
\hline & Informant 6 & Product Supply Director \\
\hline & Informant 7 & Marketing Manager \\
\hline & Informant 8 & Senior Demand Planner \\
\hline & Informant 9 & LIP/RIP Manager \\
\hline & Informant 10 & Audit Manager \\
\hline & Informant 11 & Trade Marketing Coordinator \\
\hline & \multirow{4}{*}{$\begin{array}{l}\text { Project Note Book } \\
\text { (data gathered through } \\
\text { participant observation and } \\
\text { numerous informal discussions) }\end{array}$} & NPD Manager \\
\hline & & Marketing Manager \\
\hline & & Marketing Controller \\
\hline & & Demand Planning Director \\
\hline \multirow{5}{*}{$\begin{array}{l}\text { MOP } \\
\text { Household care and healthcare } \\
\text { organisation }\end{array}$} & Informant 12 & Marketing Strategy and Planning Manager \\
\hline & Informant 13 & Customer Services and Logistics Manager \\
\hline & Informant 14 & Marketing Strategy and Planning Manager \\
\hline & Informant 15 & Finance Manager \\
\hline & Informant 16 & Customer Business Development Manager \\
\hline \multirow{3}{*}{$\begin{array}{l}\text { CAKE } \\
\text { Hot drinks/foodstuffs provider }\end{array}$} & Informant 17 & Creative Director and Board Member \\
\hline & Informant 18 & Commodities Director and Board Member \\
\hline & Informant 19 & Operations Manager \\
\hline
\end{tabular}

potential deletion candidates. A similar situation exists in relation to the managerial evaluation variables. Other deletion stages contain both strategic and tactical elements. When considering revitalisation and implementation, for instance, both strategic and tactical elements are present - the decision to revitalise a product or implement a deletion plan is strategic; however, how this occurs is clearly tactical. A potentially more problematic area is distribution. Webster $(1992,2005)$ indicates that distribution is a tactical consideration. Nevertheless, within the deletion context, distribution can also be seen as strategically relevant, for example, with respect to the development of new markets. Bearing these issues in mind, Figure I provides an insight into the various components associated with each stage of the product deletion decision-making process.

For further information on the literature associated with each of the variables outlined in Figure I refer to the appropriate appendices. 


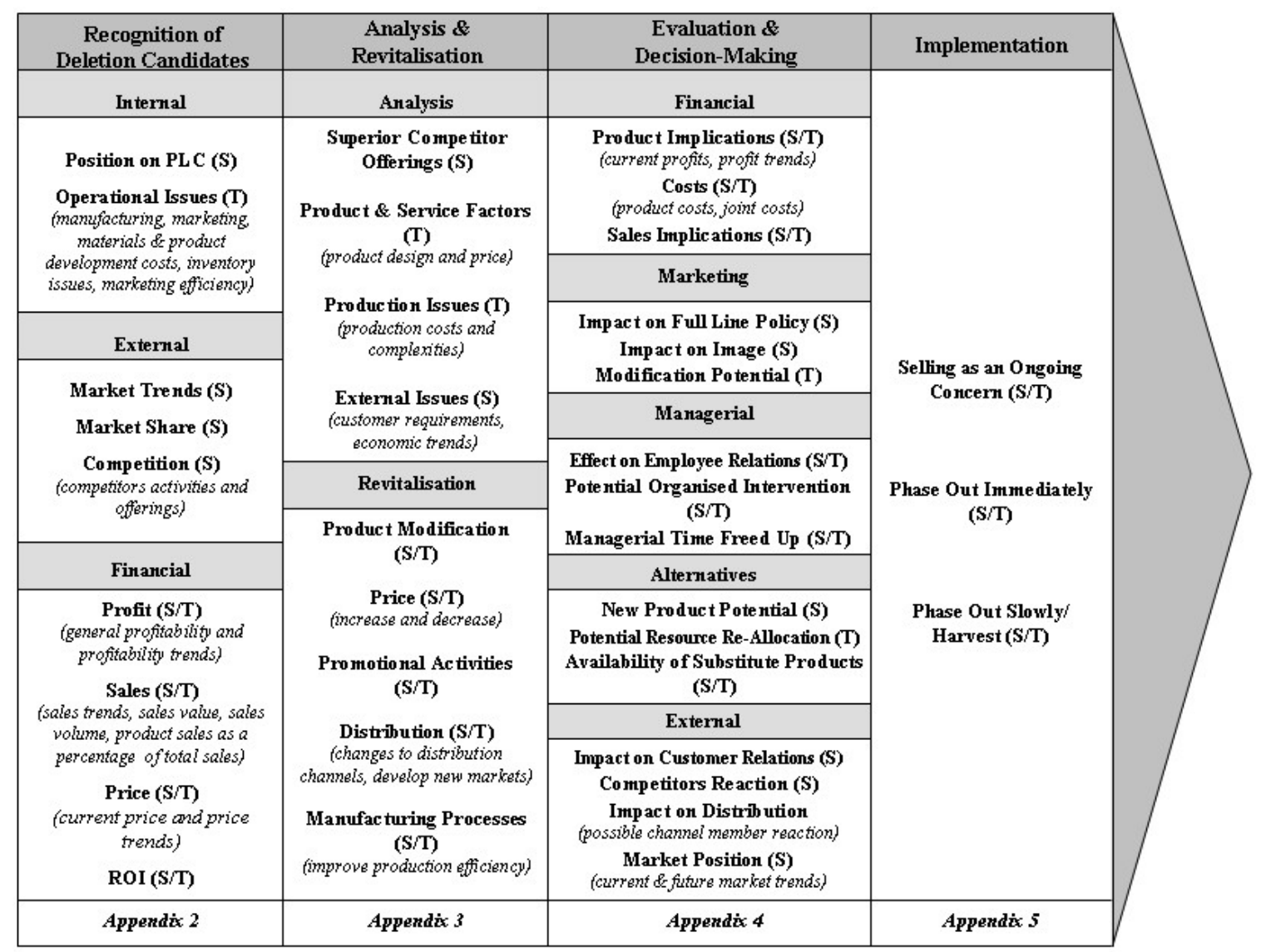

Figure 1: The product deletion process - recurring deletion variables

\section{Additional issues and cultural considerations}

The literature analysis revealed four recurring cultural issues (e.g. types of behaviour) influencing product deletion decision-making, namely the frequency of deletion activities, participants in the process, formality of the process and the socio-political influences on deletion decision-making. The following discussion draws on the findings from the literature and highlights the central themes associated with each of these cultural considerations. In order to provide a contemporary insight the information contained in the literature is compared to the experiences of the three case study organisations.

\section{Frequency}

The frequency with which organisations engage in product deletion activities has been subject to ongoing debate. Hise and McGinnis (1975) and Hise, Parasuraman and Viswanathan (1984) commenting on two separate studies, purported that $62 \%$ and $79 \%$ of the Fortune 500 organisations sampled reviewed their products' performance at least annually. In contrast to this, Avlonitis and James (1982) and Avlonitis (1986) found that less than a third of industrial goods manufacturers operating in the engineering sector reviewed 
their product portfolios on a regular basis. A diligent approach, reviewing product portfolios on a 'regular', 'periodic' and/or 'ongoing' basis, is recommended by several authors (Rothe, 1970; Worthing, 1975; Salerno, 1982; Avlonitis 1986, 1987; Boltin and Gorneau, 1998). However, as Hart (1990), Snelson and Hart (1991) and Vyas (1993) suggest, such diligence should perhaps be tempered by need, with organisations engaging in deletion activities as and when new products are introduced. The data from Mop, Tablet and Cake provides a further insight into the frequency with which organisations engage in product deletion activities. In the case study organisations product performance is reviewed on a regular basis. This trend toward regular product reviews does not, however, lead on to regular product deletions. Informants from all three organisations indicate that the actual deletion of a product is something of a rarity (informants 5, 6, 14, 15, 16, 17, 18) with product deletion generally related to the introduction of new products. For example, in Mop the introduction of a new product prompts the product deletion process: 'Every time you bring in new SKUs [stock keeping units] one should go out' (informant 13). Within the case study organisations there appears to be a belief in the need for regular product portfolio reviews. However, there also appears to be a degree of hesitation with deletion activities occurring only when strictly necessary. As such, when deletion occurs the candidate is easily identifiable. In Cake, deletion tends to occur every three to four years with a situation prevailing whereby 'by the time we come to delete something the [deletion] candidate is going "it's me" [and] we all know that's the one that's got to go' (informant 17). Managers from Mop convey similar opinions with product deletion likely to occur when a product is unsalvageable or in one manager's words 'dead' (informant 14).

\section{Formality}

Writing from a theoretical perspective, several authors postulated that the majority of organisations approach product deletion decision-making in a haphazard, ad hoc manner (Alexander, 1964; Kotler, 1965; Hamelman and Mazze, 1972; Michael, 1971). Empirical studies from the 1970s and 1980s found that less than a third of the Fortune 500 organisations involved had a deletion decision-making procedure in print (Hise and McGinnis, 1975; Hise, Parasuraman and Visanathan, 1984). This ad hoc approach to deletion decision-making appears to remain in today's environment, as similar trends emerge from two of the three case study organisations. Within Tablet: 'We don't really have a policy, what we have is a series of initiatives that when a number of SKUs get too many or too complex somebody will say, oh we need to do an exercise here' (informant 6). Similarly in Cake: 'We are not formalised and rigid ... I don't have a piece of paper or a process that we go through' (informant 18). Should organisations be concerned about the lack of a formalised approach to deletion decision-making? It would appear so, as organisations adopting a more formalised approach are more likely to identify poorly performing products (Avlonitis, 1985). They are also more likely to emphasise courses of action other than deletion, consider the re-allocation of resources and the impact of deletion on marketing, social and ethical issues. 
Further, a formalised approach allows for: 'Much less chance of retaining unprofitable or obsolete products' (Avlonitis 1985, p. 50). It is, as such, unsurprising that within the two case study organisations previously mentioned, there has, in recent years, been a change towards a more formalised deletion decision-making process (informants $2,4,5,9,17$ ).

While a formalised approach can be advantageous there is a suggestion that the degree of formality should be tempered by organisational circumstances. An informant from Mop indicated that: 'Each franchise [product] has a different level of complexity and different issues and opportunities to deal with' (informant 14). Thus, in the case study organisations a culture pervades whereby the formalised approach to deletion decision-making is modified in accordance with individual circumstances with formal processes often used alongside a more informal, often intuitive, decision-making style.

\section{Participation}

Theoretically, a range of departmental opinions should be sought prior to deleting a product (Browne and Kemp, 1976; Boltin and Gorneau, 1998). Empirical studies appear to verify this stance (Avlonitis, 1983, 1984, 1986a; Vyas, 1993; Greenley and Bayus, 1994). Table 2 offers a detailed summary on the differing viewpoints as to who should be involved in product deletion decision-making.

The findings from the recent study concur with the conceptual and empirical literature indicating that representatives from a number of managerial disciplines are likely to be involved in the deletion decision-making process: 'it's a multi-functional thing' (informant 14) involving a: 'vast diversion of views' (informant 4). However, the marketing department (Rothe, 1970; Hise and McGinnis, 1975; Avlonitis, 1984, 1985; Lambert and Sterling, 1985; Hart, 1990; Vyas, 1993; Avlonitis, Hart and Tzokas, 2000) and the accounting and finance department (Rothe, 1970; Lambert and Sterling, 1985; Avlonitis, 1984, 1985) appear to be frequently involved. This trend is noted in the case study organisations and succinctly conveyed by a marketing manager from Tablet who states: 'Marketing and financial arguments will drive what is being manufactured' (informant 7). Interestingly, only a small number of studies comment on customer involvement in deletion decisionmaking (e.g. Avlonitis, 1983a, 1984; Avlonitis, Hart and Tzokas, 2000). In all of the case study organisations, however, customers (e.g. major retailers) are likely to be consulted prior to the deletion of a product or involved in the deletion decision-making (informants 2, 4, 5, 8, 10, 11, 12, 14, 15, 16, 17, 18). As one informant states: 'We involve them [customers] early on ... we give them an opportunity to be proactively involved' (informant 17). This may be an artefact of the sector considered. With the rise of relationship marketing, customer involvement in deletion decision-making is unlikely to be restricted to a single sector.

\section{Socio-political activities}

The decision to delete a product can mark a change for an organisation and its employees (e.g. the way resources are allocated, employees' job descriptions 


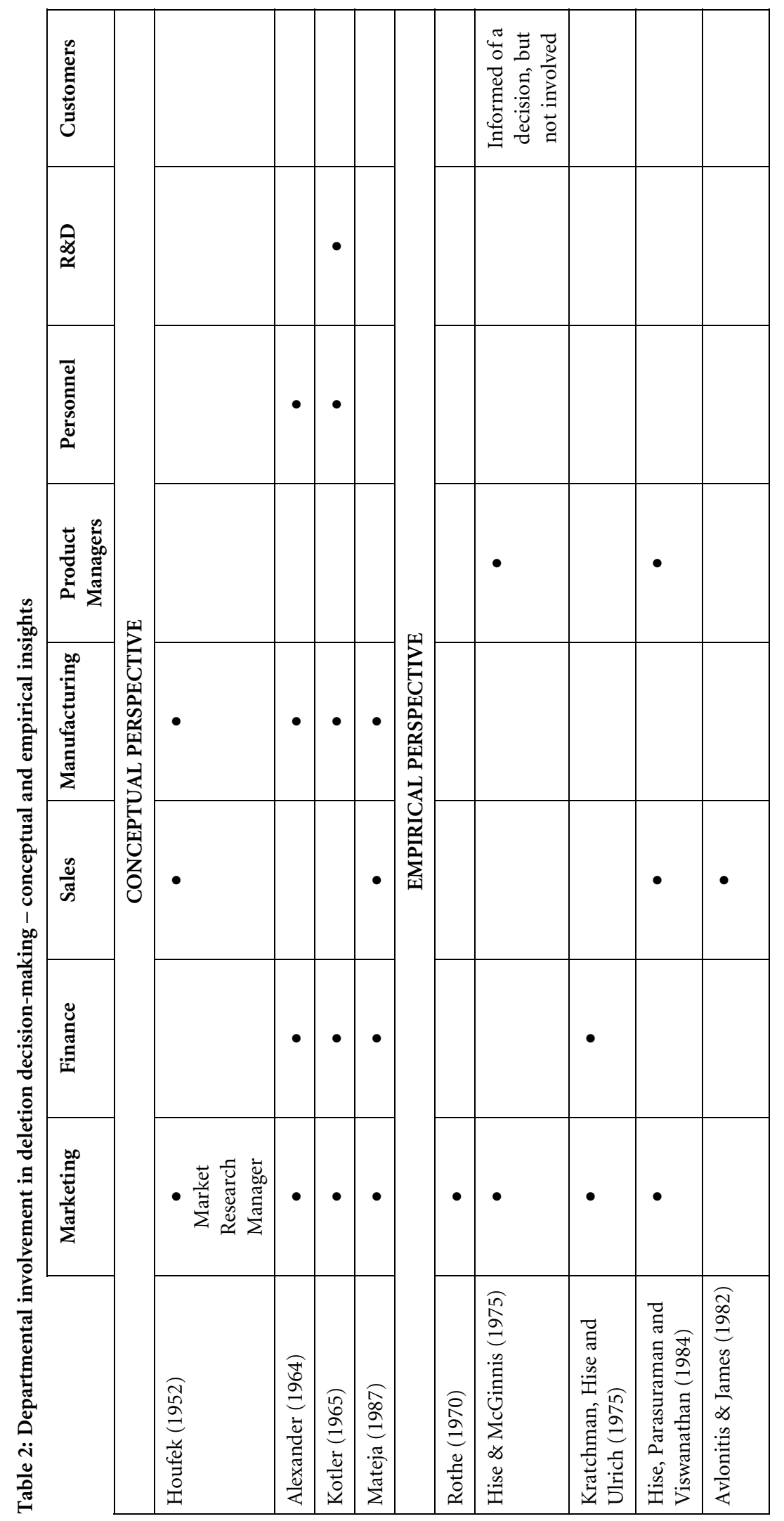




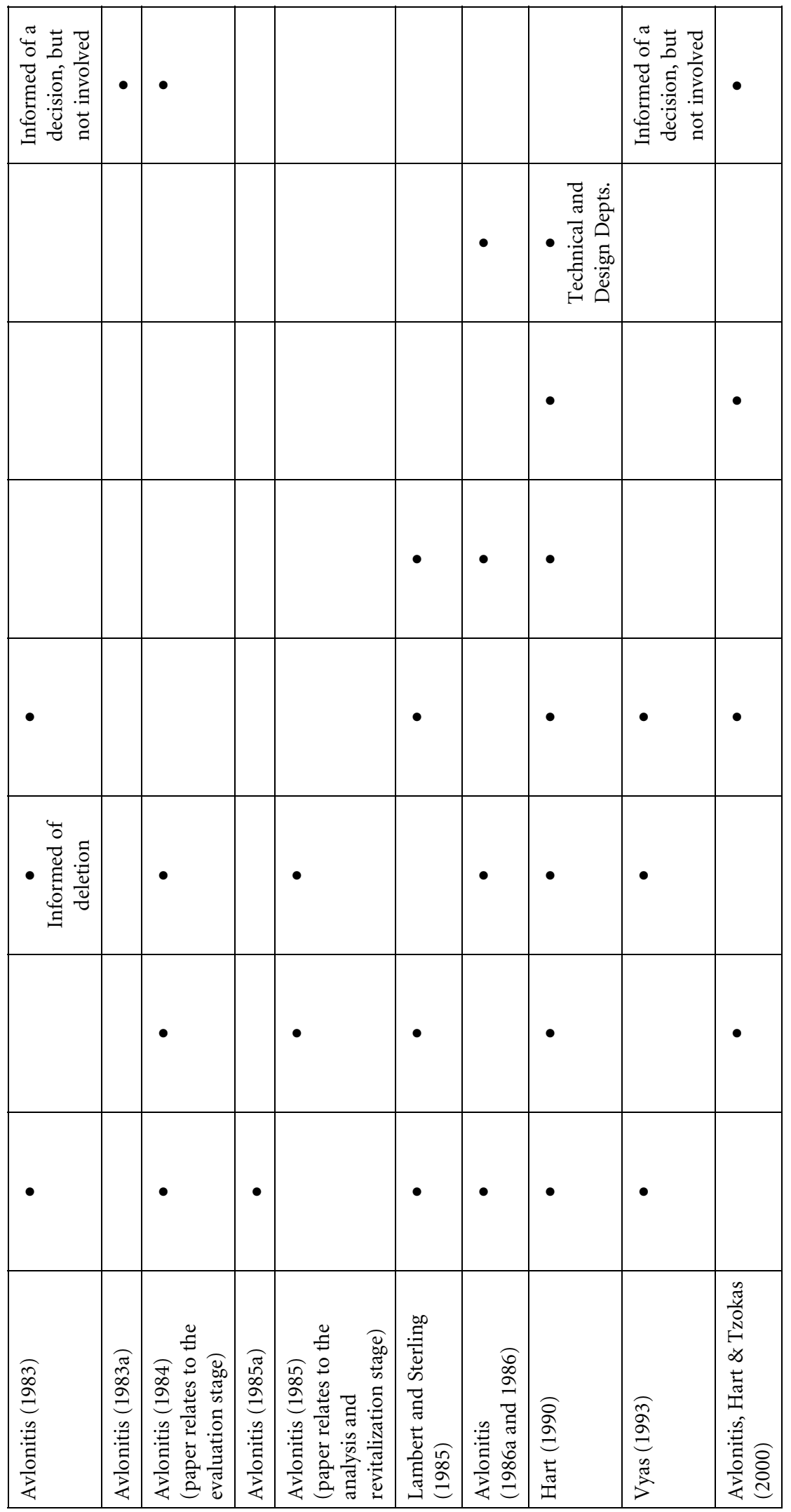


and their position within an organisation). These changes may trigger a degree of concern and negative emotions, perhaps requiring employees to address previous inadequacies, and/or disconfirming previously held beliefs (Hise and McGinnis, 1975; Burnes, 2000; Huy, 2002). It is therefore hardly surprising that the decision to delete a product is often met with resistance. While numerous reasons for this have been suggested, one common theme is employees' sentimental/emotional attachment to deletion candidates (Alexander, 1964; Kotler, 1965; Weller and Inst, 1969; Johnson, 1975; Worthing, 1975; Avlonitis, 1986a). As Michael (1971; p. 8) states, managers may be somewhat hesitant to delete a product seen as 'an old favourite, once glamorous to develop and exciting to sell, with careers and fortunes made by it and tied to it'. Similar trends are noted in the case study organisations (informants 1,6,17,19) with managers from Tablet coming up against opposition from product champions. Similarly, a board member from Cake comments that with one product it 'should have been deleted ages ago on the basis of sales, but we sort of have an emotional attachment to it' (informant 17).

Opposition to product deletion often emanates from the sales department (Bereson, 1963; Alexander, 1964; Rothe, 1970; Johnson, 1975; Browne and Kemp, 1976; Avlonitis, 1984, 1986a, 1993). Similar trends are found in the case studies with a respondent offering the following edifying comment: 'Sales people like to have as broad a product offering as possible, the more they have to sell, the more secure they are. If they have a tight range of things the danger in their mind is that if somebody doesn't want that tight range they haven't got anywhere else to go. If somebody says I don't want that, the salesman's view is how about this/that, out comes the catalogue' (informant 5). Objection to product deletion does not, however, rest solely within the organisation as customers may oppose the decision to delete a product (Bereson, 1963; Alexander, 1964; Johnson, 1975; Avlonitis, 1983a, 1984, 1986a, 1993). The case study organisations deal with a number of outlets including major retail stores, individual grocers, delicatessens (in the case of Cake) and pharmacies (in the case of Tablet). These varying customers have differing opinions on, and reactions to, product deletion. The major retailers are seen to welcome product deletion as 'they want less product on shelves earning more money so they're not going to disagree' (informant 2). However, such support is not typical of the smaller independent customers: 'Independents and possibly our own stores don't want products to go because they always have a customer' (informant 17). Each stage of the deletion decision-making process is likely to be influenced by subjective managerial judgement, informal discussions and persuasion (Avlonitis and James, 1982; Avlonitis, 1984, 1986a). Vyas (1993) drew similar conclusions highlighting the 'politicking' of product deletion. The case studies reveal socio-political trends with the vast majority of informants indicating that organisational employees are likely to use their expertise, authority, coercive abilities and network perception, their knowledge of 'people that make a difference' (informant 9) in order to both encourage and deter product deletion. It appears that a culture pervades whereby the unique circumstances encountered, and/or opposition from key stakeholders, contributes to a situation where deletion processes and procedures are balanced by the use of personal power and political acumen. 


\section{Theoretical discussion}

For organisations like Mop, Tablet and Cake operating in the FMCG sector product deletion is an increasingly important issue. Carlisle and Parker's (1989) three phase distributor/supplier relations model provides a possible explanation as to why this is the case.

Traditionally, retailers and manufacturers operated at arm's length with no one party dominating. Instead, the numerous buyers and suppliers would trade off each other (Carlisle and Parker, 1989) with retailers being seen as 'inert conduits' within the distribution process (Howe, 1998). Recently the retail sector has gone through a period of consolidation and concentration (Kotzab and Teller, 2003) with a small number of retailers becoming increasingly influential (Olver and Farris, 1989; Howe, 1998). For example, in the UK grocery sector multiple retailers (i.e. those with ten or more stores) have increased their market share from 20\% in 1950 (Howe, 1998) to a situation where four retailers currently control approximately $76 \%$ of the market (Sanderson, 2008). A similar trend has been noted across Western Europe (Dawson and Shaw, 1990).

In the face of one party (e.g. retailers) gaining a 'dominant position' Carlisle and Parker (1989) indicate that those involved will try to consolidate and/or improve their 'power position'. Currently, product deletion is playing a key role in this power play. Manufacturers have started to appreciate that high equity brands (e.g. well managed manufacturers' brands) can increase the value of retailers' own brands (Simmons, Bickart and Buchanan, 2000) helping to bolster the retailers' image (Mantrala, et al., 2009) while providing consumers with a means for comparison between manufacturer and retail brands (Grant, 2005). Manufacturers' also appreciate that the availability of key brands in store can influence consumers' retail store allegiances (Quelch and Harding, 1996). Unsurprisingly manufacturers have drawn on the aforementioned advantages in order to redress the balance of power. This involves the deletion of peripheral products and the subsequent focus on a smaller number of 'strong non-imitable brands' these being 'the best defence for manufacturers facing retailers' (Corstjens and Cortsjens, 1995; p. 61).

Carlisle and Parker's (1989) distributor/supplier relationship model contains a third stage involving a move toward joint activities and the pursuit of mutual benefits/partnerships by those involved. Hogarth-Scott and Parkinson (1993) were sceptical of such partnerships. Howe (1998) and Blois (1997) indicate that if such partnerships do develop they tend to be one sided affairs with the retailers very much in control. However, should we be so sceptical? The deletion of marginal products and the development of a select number of strong sought after brands combined with the need for retailers to deliver high quality products in a timely manner could mark the start of mutual relationships based on trust and collaboration (Cannon and Perreault, 1999). Hingley (2005) citing the work of Palmer (2000, 2002) and Cox (1999) suggests otherwise. Instead, organisations just like individuals are seen to be driven by Darwinian-like principles (e.g. self interest, continued survival) not collaboration and mutuality. As such, the current emphasis on product deletion and the shift to more concise product portfolios could merely be seen as the 
latest episode in the ever changing retailer/manufacturer power balance, with manufacturers using a potential product advantage to redress retailers' dominance (Ford, 1982).

\section{Managerial implications}

In order to provide managers with a comprehensive and practical insight into the product deletion process the relevant literature and the interview transcripts from Mop, Cake and Tablet were subject to further analysis. Rather than identify variables associated with each stage of the deletion process the aim was to extract recurrence pieces of advice/best practice appertaining to product deletion. Such information was gleaned from twenty academic papers published between 1964 and 1998 and 19 of the 23 informants. Figure 2 highlights the recurring pieces of advice/best practice. Given that two of the three organisations are industry leaders (with the third organisation a significant player in the sector) the information provided can help form the foundations of industry specific critical success factors (Leidecker and Bruno, 1984) and as such prove valuable for organisations in each of the relevant sectors.

\section{Research limitations}

In considering the recurring deletion variables significant use was made of historical literature, a retrospective approach which has some drawbacks. However, there is a need to appreciate the research context (Baker and Bettner, 1997). The aim is not to offer an industry specific or generic insight into how deletion decision-making should be addressed. Those wishing to pursue this may consult the appendices. Instead the aim is to highlight and discuss recurring issues that have emerged over nearly six decades. Another limitation already noted is the focus on a small number of FMCG organisations. This is claimed to be appropriate for exploratory study aimed at later theory building and testing. However, this affects the wider applicability and generalisation of the findings pending further investigation.

\section{Conclusions}

The paper provides food for thought in relation to a number of strategic, tactical and cultural issues associated with product deletion. On the strategic level it appears that in spite of potential problems associated with an extensive product portfolio (Alexander, 1964; Kotler, 1965), the proactive management of the product deletion process is, for the most part, a relatively new phenomenon. In the light of the recent interest in product portfolio management the clarification of the recurring variables associated with each stage of the product deletion decision-making process and the disclosure of further factors influencing deletion decision-making is timely. As Taylor (2008, p. 13) suggests: 'If you don't get ruthless with your non-core products, you may end up watching someone else ... do it for you'. 
1. Treat Product Deletion as an On-Going Strategic Activity: Do not view product portfolio assessment and deletion activities as a major event carried out every few years and/or when the organization faces a crisis. Instead incorporate product portfolio analysis and deletion considerations into the organisation's on-going strategic decision making activities.

2. Pragmatic Deletion Decision-Making: Where appropriate establish deletion decision making processes. However do not adopt a generic approach to deletion decision making, appreciate and accommodate the unique contextual conditions surrounding each deletion decision making scenario.

3. Ensure Deletion Decisions Are Based on Reliable, Relevant Data: When considering the costs associated with each product take into account all the non-arbitrary, marketing and manufacturing costs on a product-by-product basis.

4. Clearly Define Deletion Decision-Making Responsibilities: Establish clear deletion decision-making responsibilities within the organisation. Deletion decision making should involve senior managers

5. Draw on a Wide Range of Opinions: When considering deletion activities information should be gleaned from a wide range of internal and external stakeholders.

6. Do Not Neglect Customers and Consumers: When deleting a product customers should be kept informed of any decisions made. The degree of customer involvement should, however, be managed to ensure the organization maintains control over the make-up of the portfolio. Similarly consumer concerns need to be addressed with consideration being given to the consumer characteristics (e.g. how attractive and loyal are the consumers?) In the event of a product being deleted can consumers be directed toward a similar product produced by the organization?

7. Co-Ordinate New Product Development and Product Deletion Activities: Unless circumstances allow (e.g. rapid growth in a particular sector) look to delete a product as/when new products are introduced.

Figure 2: Key considerations in product deletion decision-making

\section{Appendix I: Organisation classification scheme}

\begin{tabular}{|l|l|l|}
\hline Sector & Abbreviation & Examples \\
\hline Fast Moving Consumer Goods & FMCG & snacks, soft drinks, razor blades \\
\hline Industrial Operating Supplies & IOS & $\begin{array}{l}\text { dry groceries proprietary pharmacies, small hardware items, } \\
\text { industrial operating supplies }\end{array}$ \\
\hline Consumer Durables & CD & $\begin{array}{l}\text { televisions, major household appliances, tyres, major sporting/ } \\
\text { athletic equipment }\end{array}$ \\
\hline Industrial Components & IC & heavy farm machinery \\
\hline Capital Equipment & CE & electric generators, turbines, specialised machine tools \\
\hline All of the Above & ALL & \\
\hline
\end{tabular}




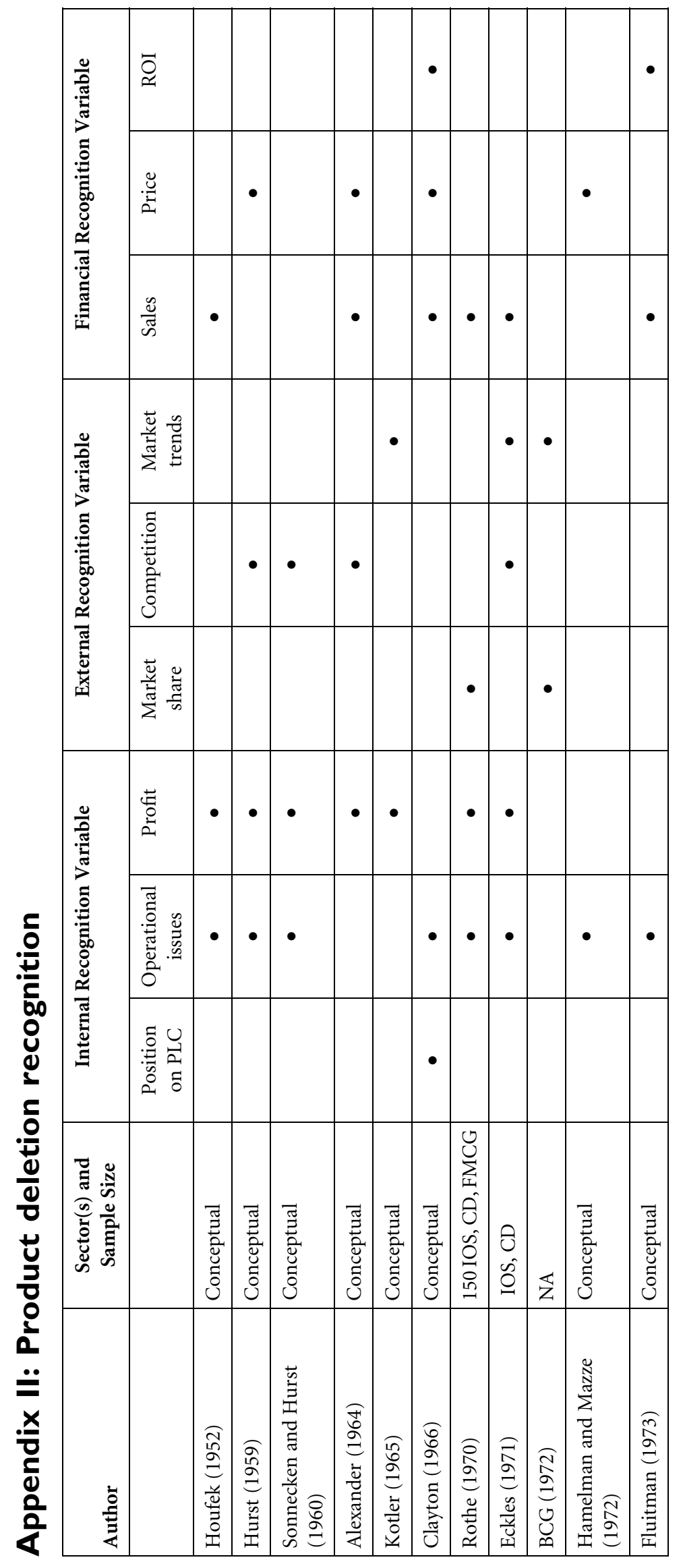




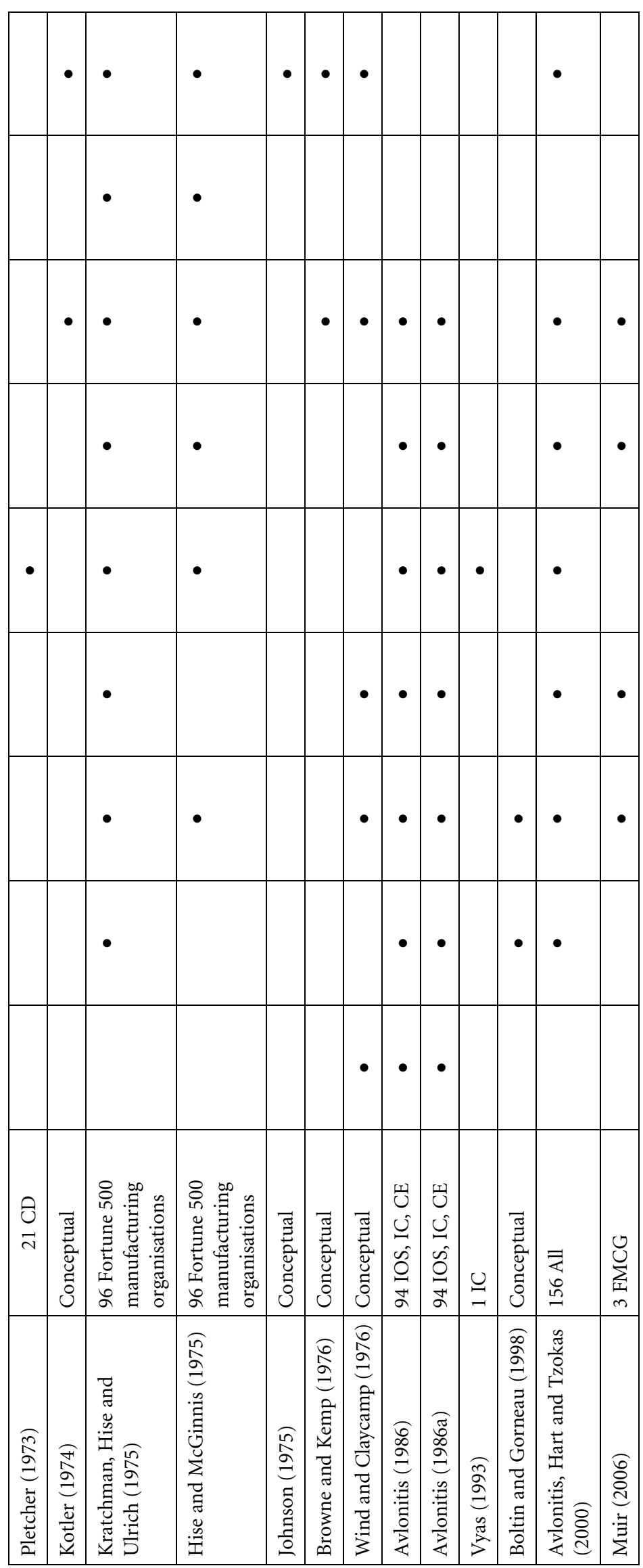




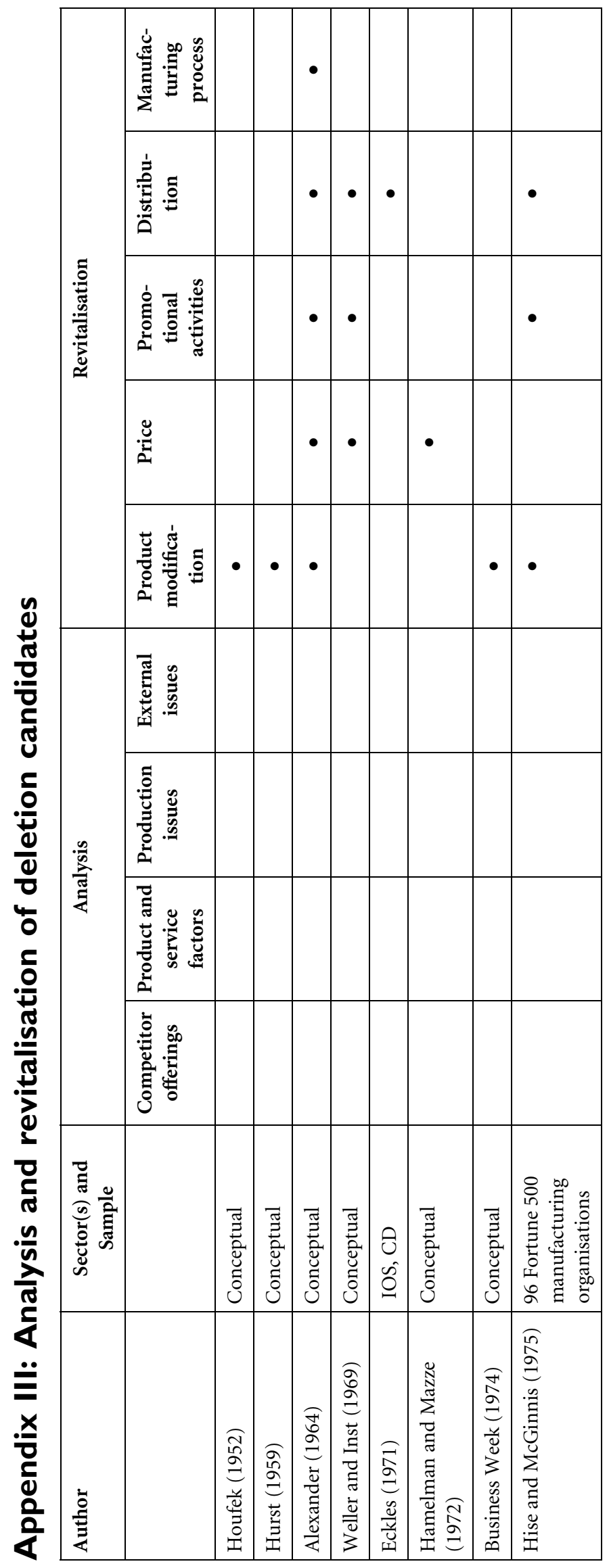




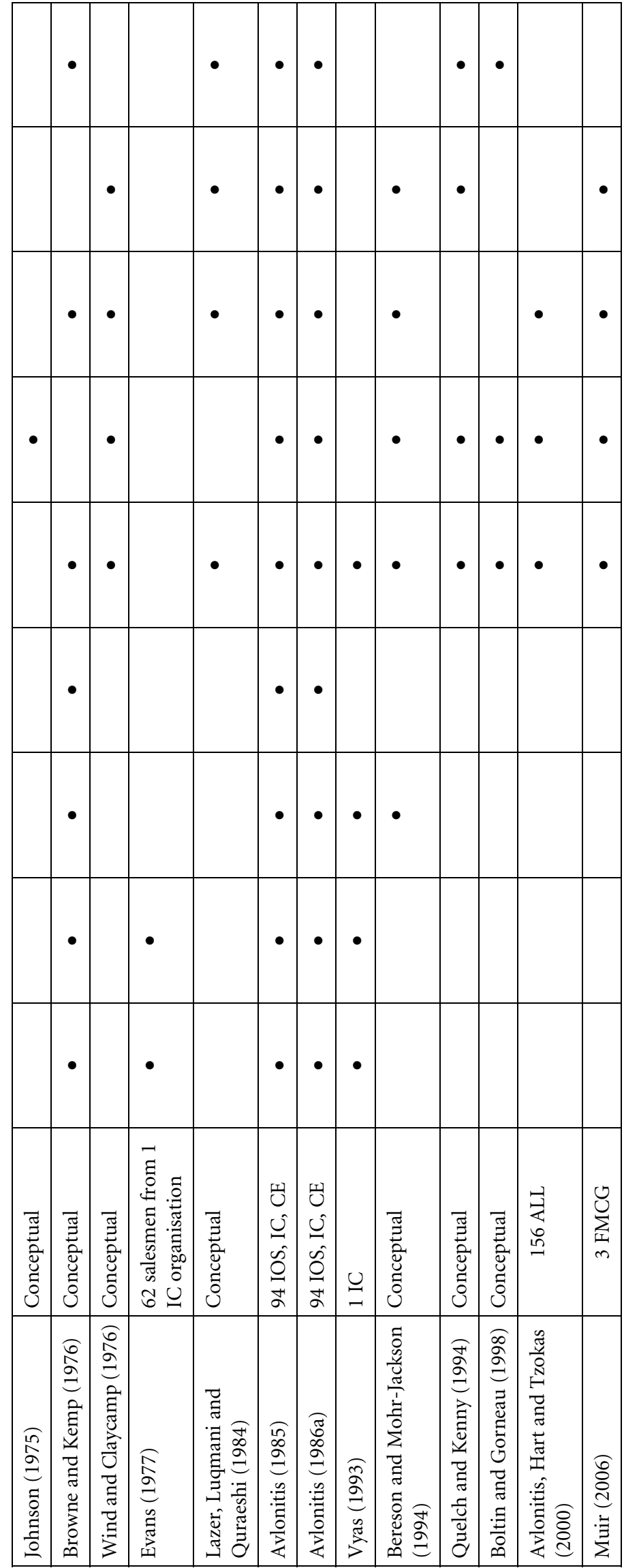




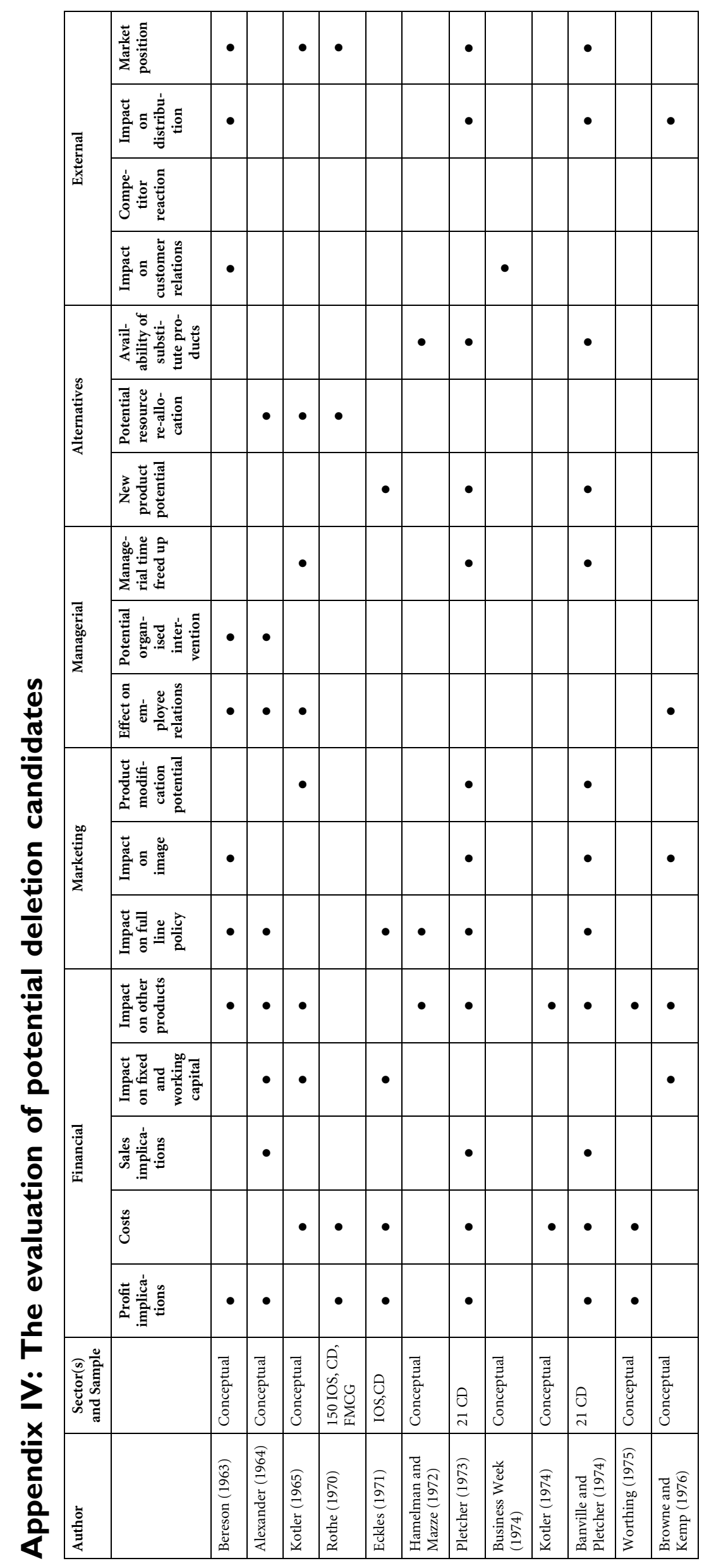




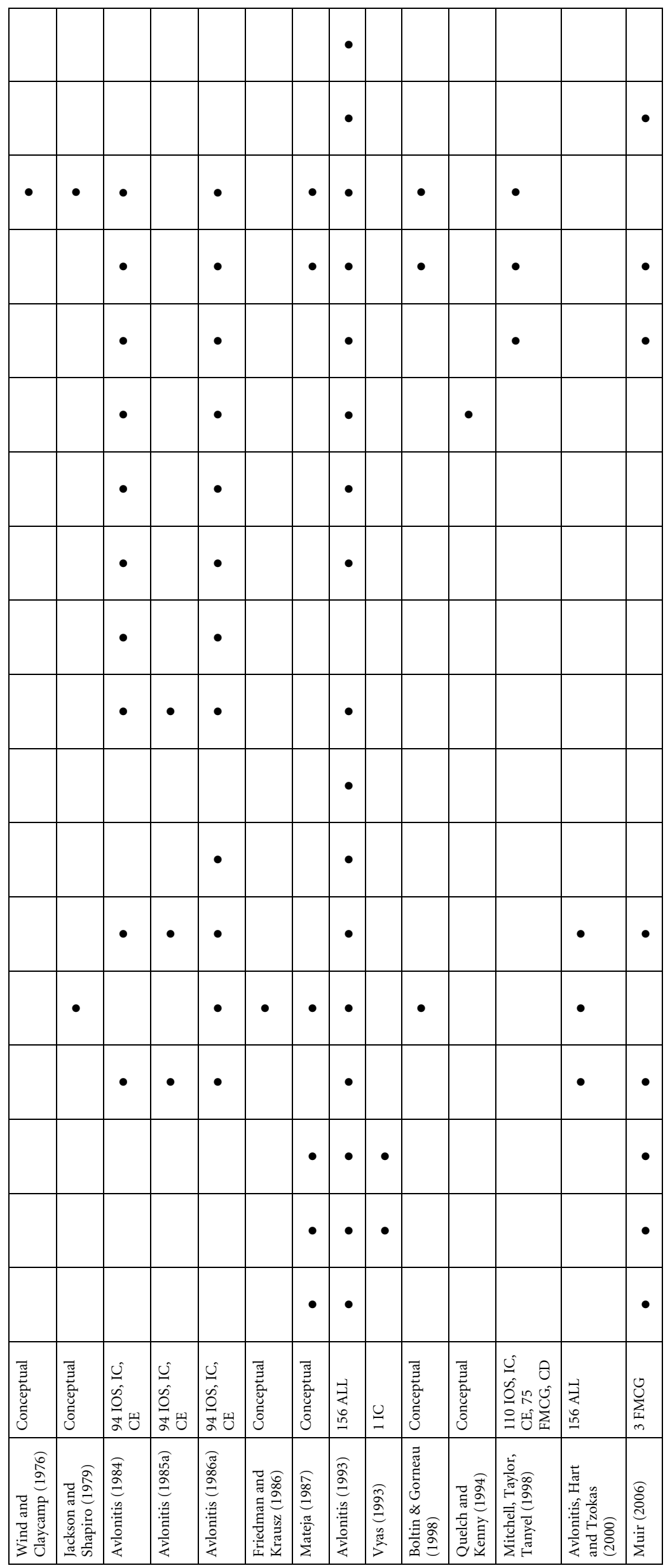




\section{Appendix V: Deletion decision - implementation}

\begin{tabular}{|c|c|c|c|c|c|}
\hline Author & Sector(s) & $\begin{array}{l}\text { Sell as ongoing } \\
\text { concern }\end{array}$ & $\begin{array}{l}\text { Phase out } \\
\text { immediately }\end{array}$ & $\begin{array}{l}\text { Phase out slowly/ } \\
\text { milk }\end{array}$ & Harvest \\
\hline Hirst (1959) & Conceptual & & & • & \\
\hline Alexander (1964) & Conceptual & $\bullet$ & $\bullet$ & & \\
\hline Talley (1964) & Conceptual & & & & $\bullet$ \\
\hline Kotler (1965) & Conceptual & $\bullet$ & & $\bullet$ & \\
\hline Rothe (1970) & $\begin{array}{l}150 \text { IOS, CD, } \\
\text { FMCG }\end{array}$ & & & $\bullet$ & \\
\hline Eckles (1971) & IOS, CD & & $\bullet$ & $\bullet$ & \\
\hline Michael (1971) & Conceptual & & & & $\bullet$ \\
\hline $\begin{array}{l}\text { Wind and } \\
\text { Claycamp (1976) }\end{array}$ & Conceptual & & $\bullet$ & • & \\
\hline Kotler (1978) & Conceptual & & & & $\bullet$ \\
\hline Avlonitis (1983) & 94 IOS, IC, CE & $\bullet$ & $\bullet$ & $\bullet$ & \\
\hline Avlonitis (1986a) & 94 IOS, IC, CE & $\bullet$ & & $\bullet$ & \\
\hline Mateja (1987) & Conceptual & & $\bullet$ & & \\
\hline $\begin{array}{l}\text { Bereson, Mohr- } \\
\text { Jackson (1994) }\end{array}$ & Conceptual & $\bullet$ & & & $\bullet$ \\
\hline $\begin{array}{l}\text { Boltin and } \\
\text { Gorneau (1998) }\end{array}$ & Conceptual & & & & $\bullet$ \\
\hline $\begin{array}{l}\text { Avlonitis, Hart } \\
\text { and Tzokas (2000) }\end{array}$ & 156 ALL & $\bullet$ & $\bullet$ & $\bullet$ & \\
\hline Muir (2006) & 3 FMCG & $\bullet$ & $\bullet$ & $\bullet$ & \\
\hline
\end{tabular}

\section{Acknowledgement}

Many thanks to Professor Joep Cornelissen for his valuable comments on an earlier draft of this paper.

\section{References}

Alexander, R. S. (1964), 'The Death and Burial of Sick Products', Journal of Marketing, Vol. 28 , pp. 1-7.

Argouslidis, P. C. and McLean, F. (2003), 'Service Elimination Decision-Making: Analysis of Candidates for Elimination and Remedial Actions', Journal of Marketing Management, Vol. 19, pp. 307-344.

Avlonitis, G. J. and James, B. G. S. (1982), 'Some Dangerous Axioms of Product Elimination Decision Making', European Journal of Marketing, Vol. 16, No. 1, pp. 36-48.

Avlonitis, G. J. (1983), 'The Product-Elimination Decision and Strategies', Industrial Marketing Management, Vol. 12, pp. 31-43.

Avlonitis, G. J. (1983a), 'Ethics and Product Elimination', Management Decision, Vol. 21, No. 2, pp. 37-45. 
Avlonitis, G. J. (1984), 'Industrial Product Elimination: Major Factors to Consider', Industrial Marketing Management, Vol. 13, pp. 77-85.

Avlonitis, G. J. (1985), 'The Techno-Economic Ecology of the Product Elimination Process', International Journal of Research in Marketing, Vol. 2, pp. 175-184.

Avlonitis, G. J. (1985a), 'Product Elimination Decision Making: Does Formality Matter?', Journal of Marketing, Vol. 49, pp. 41-52.

Avlonitis, G. J. (1986), 'The Identification of Weak Industrial Products', European Journal of Marketing, Vol. 20, No. 10, pp. 24-42.

Avlonitis, G. J. (1986a), 'The Management of the Product Elimination Function: Theoretical and Empirical Analysis', in: Woodside, A., Advances in Business Marketing, Vol. 1, pp. 1-65, Greenwich CT: JAI Press.

Avlonitis, G. J. (1987), 'Linking Different Types of Product Elimination Decisions to Their Performance Outcome: Project Dropstrat', International Journal of Research in Marketing, No. 4, pp. 43-57.

Avlonitis, G. J. (1989), 'Project Dropstrat: Product Elimination and the Product Life Cycle Concept', European Journal of Marketing, Vol. 24, No. 9, pp. 55-67.

Avlonitis, G. J. (1993), 'Project Dropstrat: What Factors do Managers Consider in Deciding Whether to Drop a Project?', European Journal of Marketing, Vol. 27, No. 4, pp. 35-57.

Avlonitis, G. J. Hart, S. J. and Tzokas, N. X. (2000), 'An Analysis of Product Deletion Scenarios', Journal of Product Innovation Management, Vol. 17, Issue 1, pp. 41-56.

Baker, R. and Bettner, M. (1997), 'Interpretive and Critical Research in Accounting: A Commentary on its Absence from Mainstream Accounting Research', Critical Perspectives on Accounting, Vol. 8, pp. 293-310.

Banville, G. B. and Pletcher, B. A. (1974), 'The Product Elimination Function', Journal of the Academy of Marketing Science, Vol. 2, Summer, pp. 432-446.

Bell, R. Davies, R. and Howard, E. (1997), 'The Changing Structure of Food Retailing in Europe: The Implications for Strategy', Long Range Planning, Vol. 30, No. 5, pp. 853-861.

Bereson, C. (1963), 'Pruning the Product Line', Business Horizon, No. 6, pp. 63-70.

Bereson, C. and Mohr-Jackson, I. (1994), 'Product Rejuvenation: A Less Risky Alternative to Product Innovation', Business Horizons, Vol. 37, No. 6, pp. 51-58.

Betts, P. (2006), 'Companies Scaling the Barriers with Record Deals', Financial Times, 28th March, pp. 20.

Blois, K. J. (1997), 'Are Business-to-Business Relationships Inherently Unstable?', Journal of Marketing Management, Vol. 13, pp. 367-382.

Boltin, G. and Gorneau, S. (1998), 'Why You Must Crop Your Products: If You Want to Cultivate Your Bottom Line, Try Trimming Your Product Line', Financial Executive, Vol. 14, No. 4, pp. 18-23.

Boston Consultancy Group (1972), Perspectives on Experience, Boston: Boston Consultancy Group.

Browne, W.G. and Kemp, P. S. (1976), 'A Three Stage Product Review Process', Industrial Marketing Management, No. 5, pp. 333-352.

Buckley, N. (2002), 'Reconditioned P\&G Continues to Shine Consumer Products Restored Focus on Core Brands Adds to Benefits of Restructuring', Financial Times, 30th October, pp. 27.

Burnes, B. (2000), Managing Change: A Strategic Approach to Organisational Dynamics (3rd edition), Harlow, Essex: Prentice Hall.

Business Week (1974), 'The Squeeze on Product Mix', 5th January, pp. 50-55.

Cannon, J. P. and Perreault, W. D. (1999), 'Buyer-Seller Relationships in Business Marketing', Journal of Marketing Research, Vol. XXXVI, November, pp. 439-460.

Carlisle, J. A. and Parker, R. C. (1989), Beyond Negotiation, Chichester: Wiley.

Carroll, J. and Johnson, E. (1990), Decision Research: A Field Guide, London: Sage Publications.

Clayton, H. L. (1966), 'The Pruning of Sick Products', Management Accounting, June, pp. 17-18.

Cooper, R. Edgett, S. and Kleinschmidt, E. (1999), 'New Product Portfolio Management: Practices and Performance', Journal of Product Innovation Management, Vol. 16, pp.333-351.

Corstjens, J. and Corstjens, M. (1995), Store Wars: The Battle for Mindspace and Shelfspace, Chichester: Wiley. 
Cox, A. (1999), 'Power, Value and Supply Chain Management', Supply Chain Management: An International Journal, Vol. 4, No. 4, pp. 167-175.

Dawson, J. A. and Shaw, S. A. (1990), 'The Changing Character of Retailer-Supplier Relationships', Retail Distribution Management, pp. 19-39.

Day, G. (1977), 'Diagnosing the Product Portfolio', Journal of Marketing, Vol. 41, April, pp. 2938.

Dimitratos, P., McDonald, F. and Tüselmann, H. (2003), 'International Economic and Environmental Changes', in: Hart, S. J. Marketing Changes, pp. 8-28, London: Thomson.

Eckles, R. W. (1971), 'Product Line Deletion and Simplification', Business Horizons, October, pp. 71-76.

Easterby-Smith, M., Thorpe, R. and Lowe, A. (1997), Management Research: An Introduction, London: Sage Publications.

Evans, R. H. (1977), 'Add Soft Data to Product Elimination Decisions', Industrial Marketing Management, Vol. 6, May, pp. 91-99.

Fluitman, L.P. (1973), 'The Necessity of an Industrial Product Mix Analysis', Industrial Marketing Management, Vol. 2, pp. 345-352.

Ford, D. (1982), in: Hakan Hakansson (ed.), International Marketing and Purchasing of Industrial Goods: An Interaction Approach, Chichester: Wiley.

Friedman, H. H. and Krausz, J. (1986), 'A Portfolio Theory Approach to Solve the Product Elimination Problem', The Mid-Atlantic Journal of Business, Vol. 24, No. 2, pp. 43-48.

Frost, R. (2004), 'Forcing Brands into Early Retirement', www.brandchannel.com, 2nd August.

Goldgehn, L. and Lagrace, R. (1983), 'Giving a New Dimension to Product Portfolio Analysis', Management Review, April, pp. 57-61.

Grant, J. (2005), 'Lafley Learns from Gillette as P\&G Moves to Next Level', Financial Times, December 21st.

Greenley, G. E. and Bayus, B. L. (1994), 'A Comparative Study of Product Launch and Deletion Decisions in UK and US Companies', European Journal of Marketing, No. 28, pp. 5-29.

Hambrick, D. C. (1983), 'An Empirical Typology of Mature Industrial-Product Environments', Academy of Management Journal, Vol. 26, pp. 213-230.

Hamelman, P. H. and Mazze, E. M. (1972), 'Improving Product Abandonment Decisions', Journal of Marketing, Vol. 36, pp. 20-26.

Hart, S. J. (1988), 'The Causes of Product Elimination in British Manufacturing Companies', Journal of Marketing Management, Vol. 3, No. 2, pp. 328-343.

Hart, S. J. (1989), 'Product Deletion and the Effects of Strategy', European Journal of Marketing, Vol. 23, No. 10, pp. 6-17.

Hart, S. J. (1990/1991), 'The Management Setting of the Product Deletion Decision', Irish Marketing Review, Vol. 5, Part. 3, pp. 41-54.

Hingley, M. K. (2005), 'Power to All Friends? Living with Imbalance in Supplier-Retailer Relations', International Marketing Management, No. 34, pp. 848-858.

Hise, R. T. and McGinnis, M. (1975), 'Product Elimination: Practises, Policies, and Ethics', Business Horizons, Vol. 18, pp. 25-32.

Hise, R. T., Parasuraman, A. and Viswanathan, R. (1984), 'Product Elimination: The Neglected Management Responsibility', Journal of Business Strategy, Vol. 4, No. 4, pp. 56-63.

Hogarth-Scott, S. and Parkinson, S. T. (1993), 'Retailer-Supplier Relationships in the Food Channel: A Suppliers Perspective', International Journal of Retail and Distribution Management, Vol. 21, No. 8, pp. 11-13.

Houfek, L. J. (1952), 'How to Decide which Products to Junk', Printers Inc, August, pp. 21-33.

Howe, W. S. (1998), 'Vertical Marketing Relations in the UK Grocery Trade: Analysis and Government Policy', International Journal of Retail \& Distribution Management, Vol. 26, No. 6, pp. 212-224.

Hurst, D. (1959), 'Criteria for Evaluating Existing Products and Product Lines', in: 'Analysing and Improving Market Performance', American Management Association, Management Report, No. 32, pp. 92-101.

Huy, Q. (2002), 'Emotional Filtering in Strategic Change', Academy of Management Proceedings $O D C$, pp. C1-C6.

Jackson, B. B. and Shapiro, B. P. (1979), 'New Way to Make Product Line Decisions', Harvard Business Review, May-June, pp. 139-49. 
Johnson, M. L. (1975), 'End of the Line for Weak Products', Industry Week, 15th September, pp. 25-29.

Kotler, P. (1965), 'Phasing Out Weak Products', Harvard Business Review, pp. 107-118.

Kotler, P. (1974), 'Marketing During Periods of Shortage', Journal of Marketing, Vol. 38, July, pp. 20-29.

Kotler, P. (1978), 'Harvesting Strategies for Weak Products', Business Horizons, August, pp. 15-22.

Kotzab, H. and Teller, C. (2003), 'Value-Adding Partnerships and Co-opetition Models in the Grocery Industry' International Journal of Physical Distribution and Logistics Management, Vol. 33, No. 3, pp. 268-281.

Kratchman, S. H., Hise, R. T. and Ulrich, T. A. (1975), 'Management's Decision to Discontinue a Product', Journal of Accountancy, June, pp. 50-54.

Lambert, D. M. and Sterling, J. U. (1985), 'The Product Abandonment Decision', Management Accounting, August, Vol. 67, No. 2, pp. 20-21.

Lancaster, K. (1979), Variety, Equity and Efficiency, New York, Columbia University Press.

Lazer, W. Luqmani, M. and Quraeshi, Z. (1984), 'Product Rejuvenation Strategies', Business Horizons, November-December, pp. 21-28.

Leidecker, J. K. and Bruno, A. V. (1984), 'Identifying and Using Critical Success Factors', Long Range Planning, Vol. 17, No. 1, pp. 23-32.

Mantrala, M. K., Levy, M., Kahn, B. E., Fox, E. J., Gaidarev, P., Dankworth, B. and Denish, S. (2009), 'Why is Assortment Planning so Difficult for Retailers? A Framework and Research (1987), 'Eliminating Products Can Aid Overall Sales Picture', Marketing News, Vol. 21, No. 15, pp. 9-11.

Michael, G. C. (1971), 'Product Petrifaction: A New Stage in the Life Cycle Theory', California Management Review, Vol. 14, Fall, pp. 88-91.

Michaels, A. (2000), 'P\&G May Sell Brand of Shampoo', Financial Times, 9th November, pp. 44.

Mitchell, M. A., Taylor, R. D. and Tanyel, F. (1998), 'Product Elimination Decisions: A Comparison of American and British Manufacturing Firms', International Journal of Commerce and Management, Vol. 8, No. 1, pp. 8-27.

Muir, J. J. (2006), An Investigation into the Application of a Product Deletion Typology and the Impact of Key Contextual Factors, Manchester Business School, Unpublished PhD Dissertation.

Olver, J. M. and Farris, P. W. (1989), 'Push and Pull: A One-Two Punch for Packaged Products', Sloan Management Review, Fall, pp. 53-61.

Palmer, A. (2000), 'Co-operation and Competition: A Darwinian Synthesis of Relationship Marketing', European Journal of Marketing, Vol. 34, No. 5/6, pp. 687-704.

Palmer, A. (2002), 'The Role of Selfishness in Buyer-Seller Relationships', Marketing Intelligence, Vol. 20, Issue 1, pp. 22-27.

Petromilli, M., Morrison, D. and Million, M. (2002), 'Brand Architecture: Building Brand Portfolio Value', Strategy and Leadership, Vol. 30, No. 5, pp. 22-28.

Pletcher, B. A. (1973), The Product Elimination Process in the Small Home Appliance Industry: An Empirical Study, Kent State University, Unpublished DBA Dissertation.

Proctor, R. and Hassard, J. (1990), 'Toward a New Model for Product Portfolio Analysis', Management Decision, Vol. 28, Part 3, pp. 14-17.

Quelch, J. A. and Kenny, D. (1994), 'Extend Profits, Not Product Lines', Harvard Business Review, Vol. 72, Sep/Oct, pp. 153-165.

Quelch, J. A. and Harding, D. (1996), 'Brands Versus Private Labels: Fighting to Win', Harvard Business Review, January-February, pp. 99-109.

Rothe, J. T. (1970), 'The Product Elimination Decision', MSU Business Topics, Vol. 18, Autumn, pp. $45-52$.

Salerno, F. (1982), Processus et Comportements d'Abandon de Produit: Analyse et Implications, Universite de Lille, Mars, These de Doctorat d'Etat de Science de Gestion.

Sanchatha, M. (2007), 'Sony Under Fire Over 60Gb PS3 Phase-Out Plans', Financial Times, Companies and Markets, July 18th, pp. 21.

Sanderson, R. (2008), 'Morrisons Boosts UK Grocery Market Share - TNS', www.Reuters.com, accessed 8th June, 2009. 
Schramm, W. (1971), Notes on Case Studies of Instructional Media Projects, Washington DC, Working Paper, The Academy for Educational Development.

Seth, A. (2004), 'The Ingram Partnership: Shelf Preservation Brand Owners Must Ensure Their Product is the One Retailers Have to Stock', Financial Times, 7th December, pp. 4.

Shapiro, B. B. (1977), 'Industrial Product Policy: Managing the Existing Product Line', Marketing Science Institute Report, September, pp. 77-110.

Simmons, C. J. Bickart, B. A. and Buchanan, L. (2000), 'Leveraging Equity Across the Brand Portfolio', Marketing Letters, Vol. 11, No. 3, pp. 210-212.

Snelson, P. and Hart, S. J. (1991), 'Product Policy: Perspectives on Success', in: Baker, M. J. (ed.) Perspectives on Marketing Management, Vol. 1, pp. 193-225, Chichester: John Wiley \& Sons Ltd.

Sonnecken, E. H. and Hurst, O. (1960), 'How to Audit Your Existing Products - For Profit', Management Methods, April, pp. 45-47.

Taylor, D. (2008), 'Make the Way for the Heros', The Marketer, April, pp. 13.

Talley, W. J. Jr (1964), 'Profiting from the Declining Product', Business Horizons, Vol. 7, Spring, pp. $77-84$.

Tomkins, R. (2000), 'Brands: The Perennial Conflict Between Producers and Retailers Has Entered a New Phase', Financial Times, 16th June.

Vyas, N. M. (1993), 'Industrial Product Elimination Decisions: Some Complex Issues', European Journal of Marketing, Vol. 27, No. 4, pp. 58-76.

Webster, F. E. Jr (1992), 'The Changing Role of Marketing in the Corporation', Journal of Marketing, Oct, Vol. 56, No. 4, pp. 1-17.

Webster, F. E. Jr (2005) 'Back to the Future: Integrating Marketing as Tactics, Strategy, and Organizational Culture', pp. 4-6, in: 'American Renaissance: Opportunities and Imperatives for Improving Marketing Thought, Practice, and Infrastructure', Journal of Marketing, Vol. 69, pp. 1-25.

Weller, D. G. and Inst, M. (1969), 'Run-Out Strategy - Profits from the Failing Product', Marketing Forum, November-December, pp. 15-20.

Wind, Y. and Claycamp, H. J. (1976), 'Planning Product Line Strategy: A Matrix Approach', Journal of Marketing, Vol. 40, pp. 2-9.

Wind, Y. and Mahajan, V. (1981), 'Designing Product and Business Portfolios', Harvard Business Review, January-February, pp. 155-165.

Wood, Z. (2009), 'Relying on Crumbles to Survive the Crunch', The Observer, March 1st.

Worthing, P. M. (1975), 'Improving Product Deletion Decision-Making', MSU Business Topics, Summer, pp. 29-37.

Yin, R. K. (2008), Case Study Research: Design and Methods (4th edition), California: Thousand Oaks.

Dr Jonathan Muir (PhD, Manchester Business School) is a Senior Lecturer at Bradford School of Management. He teaches current practice in marketing and corporate marketing. His research interests are product deletion, corporate and sustainable marketing. He has worked as a consultant advising governmental and private organisations in areas such as marketing and communication strategy.

Nina Reynolds is a Professor of Marketing at Southampton University Management School. Her research interests include cross-cultural research methods, improving quantitative measurement, online consumer behaviour and consumers' use of time. She has published in a range of journals including the Journal of International Business Studies, Journal of Business Research, European Journal of Marketing and International Marketing Review. 
Copyright of Journal of General Management is the property of Braybrooke Press Ltd. and its content may not be copied or emailed to multiple sites or posted to a listserv without the copyright holder's express written permission. However, users may print, download, or email articles for individual use. 